\title{
Serum sensitivity and lipopolysaccharide characteristics in Bordetella bronchiseptica, B. pertussis and B. parapertussis
}

\author{
D. W. BYRD, R. M. ROOP*, H. P. VEITt and G. G. SCHURIG
}

Department of Pathobiology, Virginia-Maryland Regiona/College of Veterinary Medicine, Virginia Polytechnic Institute and State University, Blacksburg, VA 24061, USA

\begin{abstract}
Summary. The viability of four strains of Bordetella bronchiseptica, two strains of $\boldsymbol{B}$. pertussis and one strain of $B$. parapertussis exposed to hyperimmune and pre-colostrum porcine serum was examined. Viable cell numbers $(\mathrm{cfu} / \mathrm{ml})$ of the $B$. pertussis strains and a rough strain of $B$. bronchiseptica (CSU-P-1) decreased by $99 \%$ and $99.99 \%$, respectively, after exposure for $1 \mathrm{~h}$ to porcine hyperimmune serum. In contrast, smooth $B$. bronchiseptica strains and the $B$. parapertussis strain showed no significant decrease in viable cell numbers after the same treatment. $B$. bronchiseptica strain CSU-P-1 also showed a $99 \%$ decrease in viable cell numbers after exposure to pre-colostrum porcine serum for $1 \mathrm{~h}$ whereas the other strains tested showed no decrease in viable numbers under the same conditions. Heating the hyperimmune and pre-colostrum serum at $56^{\circ} \mathrm{C}$ for $30 \mathrm{~min}$ resulted in the loss of bactericidal activity suggesting the involvement of complement in both systems. Analysis of silverstained SDS-PAGE profiles of lipopolysaccharide (LPS) extracted from the bacterial cells indicated that the smooth strains of $B$. bronchiseptica and the $B$. parapertussis strain possessed high mol. wt O-side chain-like material, whereas the $B$. pertussis strains and $B$. bronchiseptica strain CSU-P-1 did not. Gel filtration of acid-hydrolysed LPS samples indicated two distinct carbohydrate peaks for the strains with high mol. wt O-side chain-like material, whereas the other strains each yielded one distinct peak. Western-blot analysis indicated a positive reaction for anti-B. bronchiseptica antibodies to the high mol. wt $\mathrm{O}$-side chain-like material of all serum-resistant strains used in this study. The serum resistance of smooth $B$. bronchiseptica strains may be an important factor in their association with wound infections.
\end{abstract}

\section{Introduction}

Members of the genus Bordetella are aerobic, gramnegative, non-spore-forming, pleomorphic coccobacilli that typically infect the ciliated respiratory epithelium. $\boldsymbol{B}$. pertussis is a highly communicable bacterium that causes whooping cough in $\operatorname{man} ;^{1} B$. parapertussis causes a milder form of whooping cough which may go undetected. ${ }^{2} \boldsymbol{B}$. bronchiseptica is associated with respiratory disease in laboratory animals, kennel cough in dogs and atrophic rhinitis and bronchopneumonia in pigs. ${ }^{3} \boldsymbol{B}$. bronchiseptica rarely causes clinical respiratory disease in man, but has been isolated sporadically from wound infections in $\operatorname{man}^{4}$ and $\operatorname{dogs}(H$. P. Veit and R. M. Roop, unpublished observations). Unlike $B$. bronchiseptica, neither $B$. pertussis nor $B$. parapertussis has been reported to infect beyond the respiratory tract. ${ }^{1}$

Complement-dependent serum killing is an important host defence mechanism against bacterial infections. In response, some pathogenic bacteria have

Received 18 Jan. 1990; revised version accepted 15 Aug. 1990.

* Present address: Department of Microbiology and Immunology, University of Arkansas for Medical Science, 4301 W. Markham, Little Rock, Arkansas 72205-7199.

† Correspondence should be sent to Dr H. P. Veit. evolved means of avoiding this defence. One proposed way in which gram-negative bacteria may avoid complement-dependent serum killing is through the presence of high mol. wt $\mathrm{O}$-side chain material on the lipopolysaccharide (LPS). ${ }^{5-8}$ The high mol. wt O-side chains apparently block access of the activated terminal complement complex C5b-9 to the outer cell membrane, thus preventing bacterial lysis. ${ }^{5,7}$

Because $B$. bronchiseptica has been isolated from wound infections, this organism apparently can produce an invasive type of infection under certain conditions. ${ }^{4}$ This suggests that $B$. bronchiseptica can sometimes evade complement-dependent killing in serum, whereas $B$. pertussis appears more sensitive to killing by serum. This report presents the results of an investigation of the serum resistance of $B$. bronchiseptica, $B$. pertussis and $B$. parapertussis strains and its relation to their LPS characteristics.

\section{Materials and methods}

\section{Bacterial strains}

The origin and colonial morphology 9,10 of the strains used in this study are listed in the table. Stock 
Table. Origin and colonial morphology on BGS of the Bordetella strains used in this study

\begin{tabular}{|c|c|c|}
\hline Strain & Origin & $\begin{array}{c}\text { Colonial } \\
\text { morphology* }\end{array}$ \\
\hline 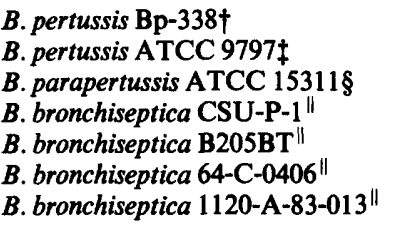 & $\begin{array}{l}\text { Human:nasopharyngeal } \\
\text { Human:nasopharyngeal } \\
\text { Human:nasopharyngeal } \\
\text { Porcine:nasal } \\
\text { Porcine:nasal } \\
\text { Canine:nasal } \\
\text { Porcine:lung }\end{array}$ & $\begin{array}{l}\text { Dom }+ \text { Scs }+ \text { Hly }+ \\
\text { Dom }+ \text { Scs }+ \text { Hly }+ \\
\text { Dom }+ \text { Scs }+ \text { Hly }+ \\
\text { Dom }- \text { Scs }- \text { Hly }- \\
\text { Dom + Scs + Hly+ } \\
\text { Dom + Scs + Hly+ } \\
\text { Dom + Scs + Hly+ }\end{array}$ \\
\hline
\end{tabular}

\footnotetext{
* Nomenclature of Peppler and Schrumpf, ${ }^{9}$ designed for describing the colonial morphology of $B$. bronchiseptica strains on BGS agar. Dom + designates the domed colony type, Scs + designates a smooth colony surface, and Hly + indicates production of a zone of haemolysis around the colony.

$\uparrow$ Obtained from Dr E. L. Hewlett, University of Virginia School of Medicine, Charlottesville, VA, USA.

$\ddagger B$. pertussis type strain obtained from the American Type Culture Collection (ATCC), Rockville, MD, USA.

$\$$ B. parapertussis type strain obtained from ATCC.

These strains have been described previously. ${ }^{10}$
}

cultures were lyophilised in skimmed milk and stored at $-70^{\circ} \mathrm{C}$. Working cultures were grown on Bordet Gengou agar supplemented with defibrinated sheep blood $15 \%$ (BGS) at $37^{\circ} \mathrm{C}$ for $48 \mathrm{~h}$ (B. bronchiseptica and $B$. parapertussis) or $72 \mathrm{~h}$ (B. pertussis) and stored at $4^{\circ} \mathrm{C}$ with bi-weekly transfer. Working cultures were transferred a maximum of four times; new working cultures were then prepared from stock cultures.

\section{Preparation and testing of serum}

Hyperimmune serum was obtained from a sow that had been immunised four times during an 8-week period with a commercial Bordetella-Pasteurella vaccine (Rhinobac, Norden Laboratories, Omaha, NE, USA). Blood was collected 2 weeks after the last vaccination. The sow was bled from an ear vein by means of a butterfly infusion set (Abbott Hospitals, Inc., North Chicago, IL, USA) and a 5-ml syringe. Blood was allowed to clot overnight at $4^{\circ} \mathrm{C}$ in a $10-\mathrm{ml}$ blood collection tube (Vacutainer, Becton Dickinson, Rutherford, NJ, USA) without additives. Serum was removed and stored at $-70^{\circ} \mathrm{C}$ until needed. Precolostrum serum was taken from a newborn piglet which had not received colostrum and thus should not have had any specific antibodies to Bordetella spp. or other antigens. ${ }^{11}$ Blood was obtained by intravenous puncture, and the serum was removed and stored as described above.

An enzyme-linked immunosorbent assay (ELISA) based on previously described procedures ${ }^{12,13}$ was used to test the serum samples for antibodies against $B$. bronchiseptica. The antigen for the ELISA was prepared as follows. B. bronchiseptica strain B205BT was grown for $48 \mathrm{~h}$ at $37^{\circ} \mathrm{C}$ on BGS. Cells were

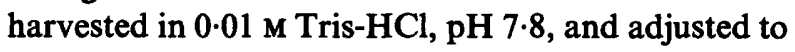
an optical density of 1.0 at $660 \mathrm{~nm}$. The cells were lysed by sonication (Fisher Sonic Dismembrator, Pittsburg, PA) with short pulses at $60 \%$ power for 30 min while being cooled in an ice bath. The lysate was centrifuged at $800 \mathrm{~g}$ for $20 \mathrm{~min}$ at $0-4^{\circ} \mathrm{C}$ and the pellet was resuspended in $0.05 \mathrm{M} \mathrm{Na}_{2} \mathrm{CO}_{3}-\mathrm{NaHCO}_{3}, \mathrm{pH} 9.6$ (coating buffer). Protein concentration was determined by the method of Lowry ${ }^{14}$ and adjusted to $50 \mu \mathrm{g} / \mathrm{ml}$. Ninety-six-well microelisa plates (Nunc, Immuno-plate II, Vangard International, Inc., Neptune, NJ, USA) with $50 \mu$ l of cell lysate per well were incubated overnight at $4^{\circ} \mathrm{C}$. Plates were washed five times with phosphate-buffered saline $(0.15 \mathrm{M} \mathrm{NaCl}$, $0.003 \mathrm{M} \mathrm{KCl}, 0.006 \mathrm{M} \mathrm{Na}_{2} \mathrm{HPO}_{4}, 0.0015 \mathrm{M} \mathrm{KH}_{2} \mathrm{PO}_{4}$, pH 7.4) supplemented with Tween $800.05 \% \mathrm{v} / \mathrm{v}$ (PBST). PBS-T (100 $\mu \mathrm{l})$ supplemented with bovine serum albumin (BSA) $1 \% \mathrm{w} / \mathrm{v}$ was added to each well and incubated at $37^{\circ} \mathrm{C}$ for $30 \mathrm{~min}$. Plates were washed five times as described above and $50 \mu \mathrm{l}$ of test or control serum diluted from 1 in 10 to 1 in 25600 in acetatebuffered saline (0.07 $\mathrm{M} \mathrm{NaC}_{2} \mathrm{H}_{3} \mathrm{O}_{2}, 0.15 \mathrm{M} \mathrm{NaCl}$, pH 5.0) supplemented with Tween-40 0.2\% v/v (ABS-T) was added to the appropriate wells and incubated for $1 \mathrm{~h}$ at $37^{\circ} \mathrm{C}$. Serum from the hyperimmunised sow was used as the positive control serum. Serum from the newborn piglet was used as the negative control serum. Wells were washed five times with ABS-T, and $50 \mu \mathrm{l}$ of peroxidase-conjugated rabbit anti-swine IgG (heavy and light chains; Cooper Biomedical, Malvern, PA, USA), diluted 1 in 800 in ABS-T, was added to each well; the plates were incubated for $30 \mathrm{~min}$ at $37^{\circ} \mathrm{C}$. Plates were washed five times with ABS-T, and $50 \mu \mathrm{l}$ of freshly-prepared substrate solution $(10 \mathrm{mg}$ of $o$ phenylenediamine dissolved in $1 \mathrm{ml}$ of methanol, in $100 \mathrm{ml}$ of distilled $\mathrm{H}_{2} \mathrm{O}$ and $100 \mu \mathrm{l}$ of $\mathrm{H}_{2} \mathrm{O}_{2}$ ) was added to each well and incubated for $5 \mathrm{~min}$ in the dark. The reaction was terminated by the addition of $10 \mu \mathrm{l}$ of 8 $\mathrm{N} \mathrm{H}_{2} \mathrm{SO}_{4}$ to each well. The absorbance at $492 \mathrm{~nm}$ was determined with an automated microelisa reader (Titertek Multiskan, Flow Laboratories, McLean, VA, USA). A positive reaction at dilutions less than 1 in 20 was considered to represent the background. 
Positive reactions at dilutions greater than 1 in 20 were considered to be Bordetella specific.

\section{Serum sensitivity assay}

Growth from a 48-h culture of $B$. bronchiseptica or $B$. parapertussis or a 72-h culture of $B$. pertussis grown on BGS at $37^{\circ} \mathrm{C}$ was used to inoculate a $16 \times 125 \mathrm{~mm}$ screw-capped glass test tube containing $5 \mathrm{ml}$ of Stainer-Scholte Broth (SSB). ${ }^{15}$ The B. bronchiseptica cultures were incubated for $8 \mathrm{~h}$, and the $B$. parapertussis and $B$. pertussis strains were incubated for $24 \mathrm{~h}$ at $37^{\circ} \mathrm{C}$ in a shaking water bath at $120 \mathrm{rpm}$. The contents of the tube were transferred to a 250-ml screw-capped glass Erlenmeyer flask containing $50 \mathrm{ml}$ of SSB, and incubated at $37^{\circ} \mathrm{C}$ in a water bath with shaking at $120 \mathrm{rpm}$ until logarithmic growth occurred $(c .5 \mathrm{~h}$ for the $B$. bronchiseptica strains and $c .12 \mathrm{~h}$ for the $B$. parapertussis and $B$. pertussis strains). The cultures were then centrifuged at $10000 \mathrm{~g}$ for $10 \mathrm{~min}$, and the cells were washed once with sterile physiological saline $(0.15 \mathrm{M} \mathrm{NaCl})$ and resuspended in sterile saline to an optical density of $0 \cdot 2$ at $525 \mathrm{~nm}$. A 10 -fold serum dilution was prepared by adding $0.2 \mathrm{ml}$ of the appropriate serum to $0.2 \mathrm{ml}$ of the bacterial culture to be tested and $1.6 \mathrm{ml}$ of Hanks's Balanced Salts Solution (Gibco Laboratories, Chagrin Falls, OH, USA) containing $0.15 \mathrm{mM} \quad \mathrm{CaCl}_{2}$ and $1.0 \mathrm{mM} \mathrm{MgCl}_{2}$ (HBSS ++ ), buffered with $10 \mathrm{~mm}$ HEPES (Sigma) and $\mathrm{NaH}_{2} \mathrm{CO}_{3} \quad 0.075 \% \mathrm{w} / \mathrm{v} .{ }^{5-8}$ Two control media were used in the assay. One consisted of $0.2 \mathrm{ml}$ of the appropriate culture with $1.6 \mathrm{ml}$ of buffered $\mathrm{HBSS}++$ plus $0.2 \mathrm{ml}$ of serum that had been heated at $56^{\circ} \mathrm{C}$ for $30 \mathrm{~min}$ to inactivate complement. The second consisted of $0.2 \mathrm{ml}$ of the appropriate culture plus $1.8 \mathrm{ml}$ of buffered HBSS ++ with no serum. All samples were incubated in $16 \times 125 \mathrm{~mm}$ sterile screw-capped glass tubes at $37^{\circ} \mathrm{C}$ in a shaking water bath at $120 \mathrm{rpm}$. At $0,20,40$, and $60 \mathrm{~min}, 100-\mu \mathrm{l}$ samples were taken from the tubes. Ten-fold dilutions in sterile saline were made of each sample. Four $10-\mu$ replicates were plated on to BGS agar for each dilution. Plates were incubated for $48-72 \mathrm{~h}$ at $37^{\circ} \mathrm{C}$ and the number of $\mathrm{cfu} / \mathrm{ml}$ was determined.

\section{LPS extraction}

Bacterial strains were grown on BGS for $72 \mathrm{~h}$ at $37^{\circ} \mathrm{C}$. Cells were harvested in distilled water and centrifuged at $10000 \mathrm{~g}$ for $10 \mathrm{~min}$, then washed twice in distilled water. LPS was extracted by the hot phenol-water method of Westphal and Jann. ${ }^{16}$ The aqueous and phenolic phases were dialysed in tubing with a mol. wt cut-off of $3.5 \mathrm{Kda}$ (Spectrapor membrane tubing, Baxter, McGaw Park, IL, USA) against distilled water for 3 days at $4^{\circ} \mathrm{C}$ with fresh water added twice daily. After dialysis, the samples were lyophilised. LPS was recovered almost entirely from the aqueous phase lyophil, which was stored in air-tight containers at $4^{\circ} \mathrm{C}$ until used.

\section{Sodium dodecyl sulphate-polyacrylamide gel electrophoresis (SDS-PAGE)}

LPS preparations were subjected to Laemmli discontinuous SDS-PAGE ${ }^{17-21}$ with the modifications of Tsai and Frasch. ${ }^{22}$ A $4 \%$ stacking and a $15 \%$ resolving gel were used. Each LPS sample was prepared at $2 \mathrm{mg} / \mathrm{ml}$ in $10 \mathrm{mM}$ Tris buffer, $\mathrm{pH} 8.0$. To $50 \mu \mathrm{l}$ of each sample, $25 \mu \mathrm{l}$ of DNAase (Sigma) stock solution was added and the preparations were incubated at $37^{\circ} \mathrm{C}$ for $1 \mathrm{~h}$. Stock solutions of DNAase were prepared at $1.0 \mathrm{mg} / \mathrm{ml}$ in $10 \mathrm{~mm}$ Tris, $\mathrm{pH} 8.0$. A stock solution $(20 \mathrm{mg} / \mathrm{ml}$ in distilled water) of proteinase $\mathrm{K}$ (Sigma) was diluted 1 in 20 with $10 \mathrm{~mm}$ Tris, $\mathrm{pH} 8 \cdot 0$, and $20 \mu \mathrm{l}$ of the diluted proteinase $\mathrm{K}$ solution was added to $100 \mu \mathrm{l}$ of each sample and incubated for $1 \mathrm{~h}$ at $60^{\circ} \mathrm{C}$. Sample buffer $(120 \mu \mathrm{l})$ was added to each sample, the mixture was boiled for $5 \mathrm{~min}$ and $12 \mu \mathrm{l}$ was applied to each lane on the gel. Gels were run at $20 \mathrm{~mA}$ constant current until the dye front reached the bottom of the gel $(c .5 \mathrm{~h})$. Gels used for Western blotting were prepared as described above, except that $36 \mu$ l of the enzymatically-digested solution was added to each lane on the gel. The polyacrylamide gels were stained with silver as described by Tsai and Frasch. ${ }^{22}$

\section{Western blotting}

A modification of the electrophoretic transfer procedure described by Towbin et al. ${ }^{23}$ was used to transfer LPS from polyacrylamide gels to nitrocellulose paper. Briefly, LPS was transferred to nitrocellulose paper (Micron Separations Inc., Westboro, MA, USA) in a transfer apparatus at a constant voltage of $25 \mathrm{~V}$ for $16 \mathrm{~h}$. All incubations after this step were performed on a table-top shaker at room temperature. The nitrocellulose paper was removed from the apparatus and incubated for $1 \mathrm{~h}$ in Tris-buffered saline (TBS) $(0.02 \mathrm{M}$ Tris-base, $0.5 \mathrm{M} \mathrm{NaCl}, \mathrm{pH} 7.5)$ supplemented with BSA $2 \% \mathrm{w} / \mathrm{v}$ (TBS-B). The paper was then washed three times with TBS supplemented with Tween-20 0.3\% v/v at $10 \mathrm{~min} / \mathrm{wash}$. Anti-B. bronchiseptica hyperimmune porcine serum diluted 1 in 100 with TBS-B was added to the paper and incubated for $2 \mathrm{~h}$. The nitrocellulose paper was washed as previously described. Peroxidase-conjugated rabbit anti-swine IgG (heavy and light chains; Cappel, Durham, NC, USA) diluted 1 in 1000 with TBS-B was then added to the paper and incubated for $2 \mathrm{~h}$. After washing, the paper was developed by adding $60 \mathrm{ml}$ of freshly prepared substrate solution $(30 \mathrm{mg}$ of 4-chloro-1naphthol dissolved in $10 \mathrm{ml}$ of methanol, in $50 \mathrm{ml}$ of TBS with $30 \mu \mathrm{l}$ of $\mathrm{H}_{2} \mathrm{O}_{2}$ ) and incubated until colour developed. The nitrocellulose paper was washed with distilled water, dried, photographed and stored in the dark.

\section{Acid hydrolysis and gel filtration}

LPS samples $(1 \mathrm{mg} / \mathrm{ml})$ were acid-hydrolysed by boiling for $2 \mathrm{~h}$ in screw-capped glass tubes containing 
acetic acid $1 \% \mathrm{v} / \mathrm{v}$. After hydrolysis, samples were centrifuged at $10000 \mathrm{~g}$ for $10 \mathrm{~min}$. The supernate, which contained the oligosaccharide fraction of the LPS, was lyophilised. The pellet, which contained the lipid-A fraction, was discarded. The lyophilised oligosaccharides were resuspended in distilled water to a concentration of $10 \mathrm{mg} / \mathrm{ml}$. Each sample (100- $\mu \mathrm{l})$ was placed on a $30 \times 1 \mathrm{~cm}$ Sephadex G-75 (Pharmacia Inc., Piscataway, NJ, USA) column which had been equilibrated with distilled water. Samples $(1 \mathrm{ml})$ were collected at a rate of $4.0 \mathrm{ml} / \mathrm{h}$, and fractions containing carbohydrate were identified by the phenol-sulphuric acid assay. ${ }^{24}$

\section{Results}

\section{ELISA titres}

The hyperimmune porcine serum had a titre of 12800 against the $B$. bronchiseptica antigen. Precolostrum porcine serum had a titre of $<10$ which indicated no measurable levels of specific antibodies to Bordetella spp.

\section{Serum sensitivity}

B. bronchiseptica strains B205BT, 64-C-0406 and 1120-A-83-013 and B. parapertussis strain ATCC 15311 maintained nearly constant viability after exposure to unheated porcine hyperimmune serum for $1 \mathrm{~h}$. In contrast, $B$. pertussis strain ATCC 9797 showed a 98\% decrease in $\mathrm{cfu} / \mathrm{ml}$ and $B$. pertussis strain $\mathrm{Bp}-338$ showed a $99 \cdot 5 \%$ decrease during the same period (fig. 1a); the rate of loss of viability was almost linear during the entire incubation period. $B$. bronchiseptica strain CSU-P-1 showed a $99.99 \%$ decrease in viable cell numbers after exposure to the unheated hyperimmune serum for $1 \mathrm{~h}$ (fig. 1a), with the largest decrease in viable cell numbers occurring during the first 20 min of incubation. B. bronchiseptica strain CSU-P-1 was the only strain tested that was sensitive to unheated pre-colostrum porcine serum (fig. 1b). This organism showed a $99.5 \%$ decrease in cell viability $(\mathrm{cfu} / \mathrm{ml})$ after $1 \mathrm{~h}$, with the decrease being almost linear. When exposed to hyperimmune or pre-colostrum porcine serum that had been heated at $56^{\circ} \mathrm{C}$ for $30 \mathrm{~min}$ to inactivate the complement, none of the seven Bordetella strains showed a measurable decrease in viable cell numbers (data not shown).

\section{LPS profiles}

LPS preparations from $B$. bronchiseptica strains B205BT, 64-C-0406 and 1120-A-83-013 and B. parapertussis showed similar smears with high mol. wt bands on silver-stained SDS-PAGE gels (fig. 2a, identified as "a"). These bands were thought to represent LPS fragments which contained high mol. wt O-side chains on core structures. Similar high mol. wt material was not present in $B$. pertussis strains nor in $B$. bronchiseptica strain CSU-P-1, although unique intermediate mol. wt bands appeared for both $B$. pertussis strains (fig. $2 \mathrm{a}$, bottom of " $\mathrm{a}$ " zone); these bands may represent intermediate mol. wt $\mathrm{O}$-side
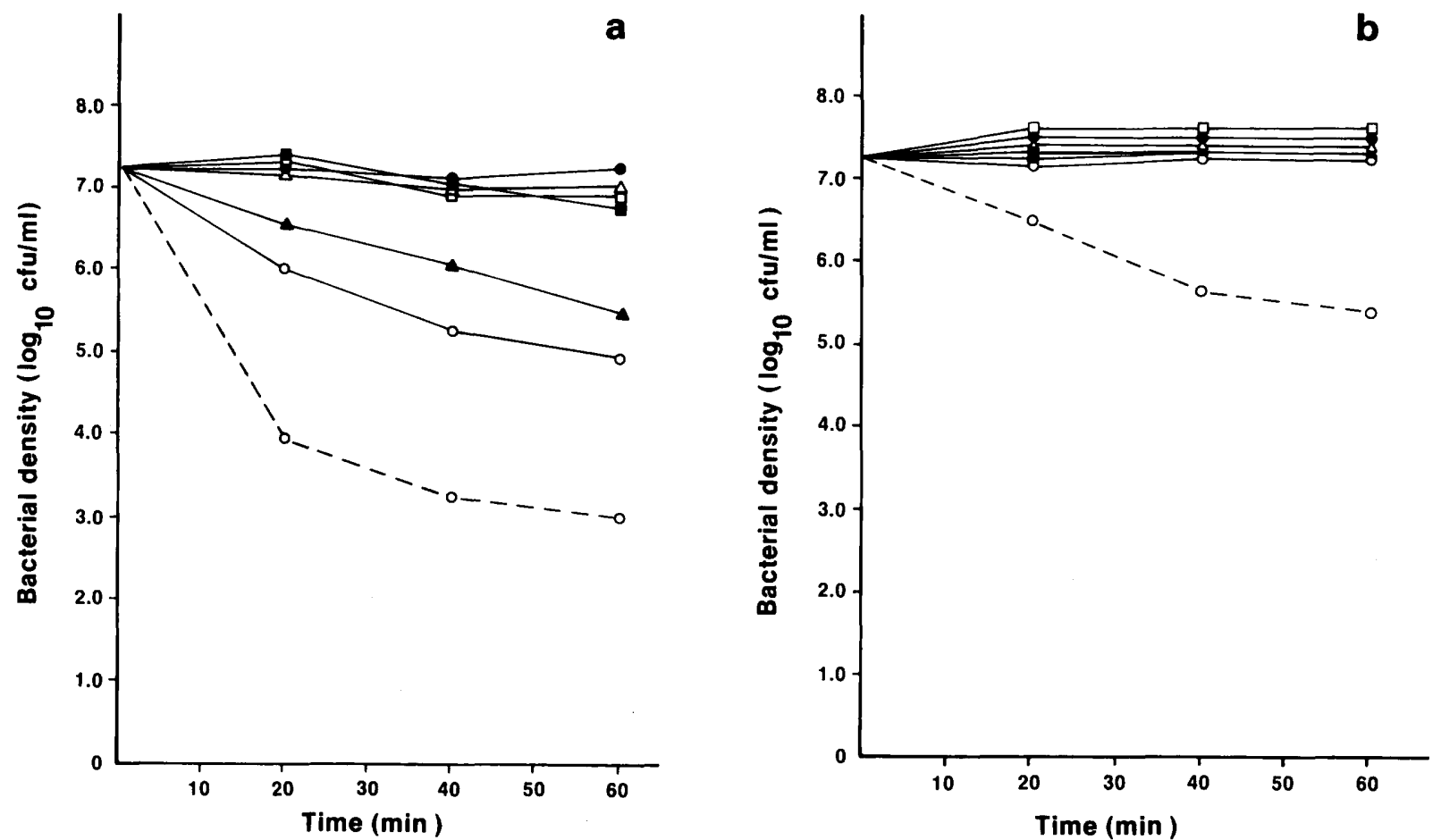

Fig. 1. Sensitivity of Bordetella strains to porcine serum: B. pertussis Bp-338 $\left(\mathrm{O}_{-} \mathrm{O}\right)$; B. pertussis ATCC $9797(\boldsymbol{A}-\mathbf{A}) ; \boldsymbol{B}$. parapertussis ATCC $15311(\square)$; B. bronchiseptica CSU-P-1 (O - - O); B. bronchiseptica B205BT ( $\square-\square)$; B. bronchiseptica 64-C-0406 $\triangle \triangle$ ( $\triangle$; B. bronchiseptica 1120-A-83-013 (- - C). (A) Unheated hyperimmune serum; (B) unheated pre-colostrum serum (NB. From 40 min to 60 min, B. pertussis ATCC 9797 and B. parapertussis ATCC 15311 have similar values, and are represented as a single line). 

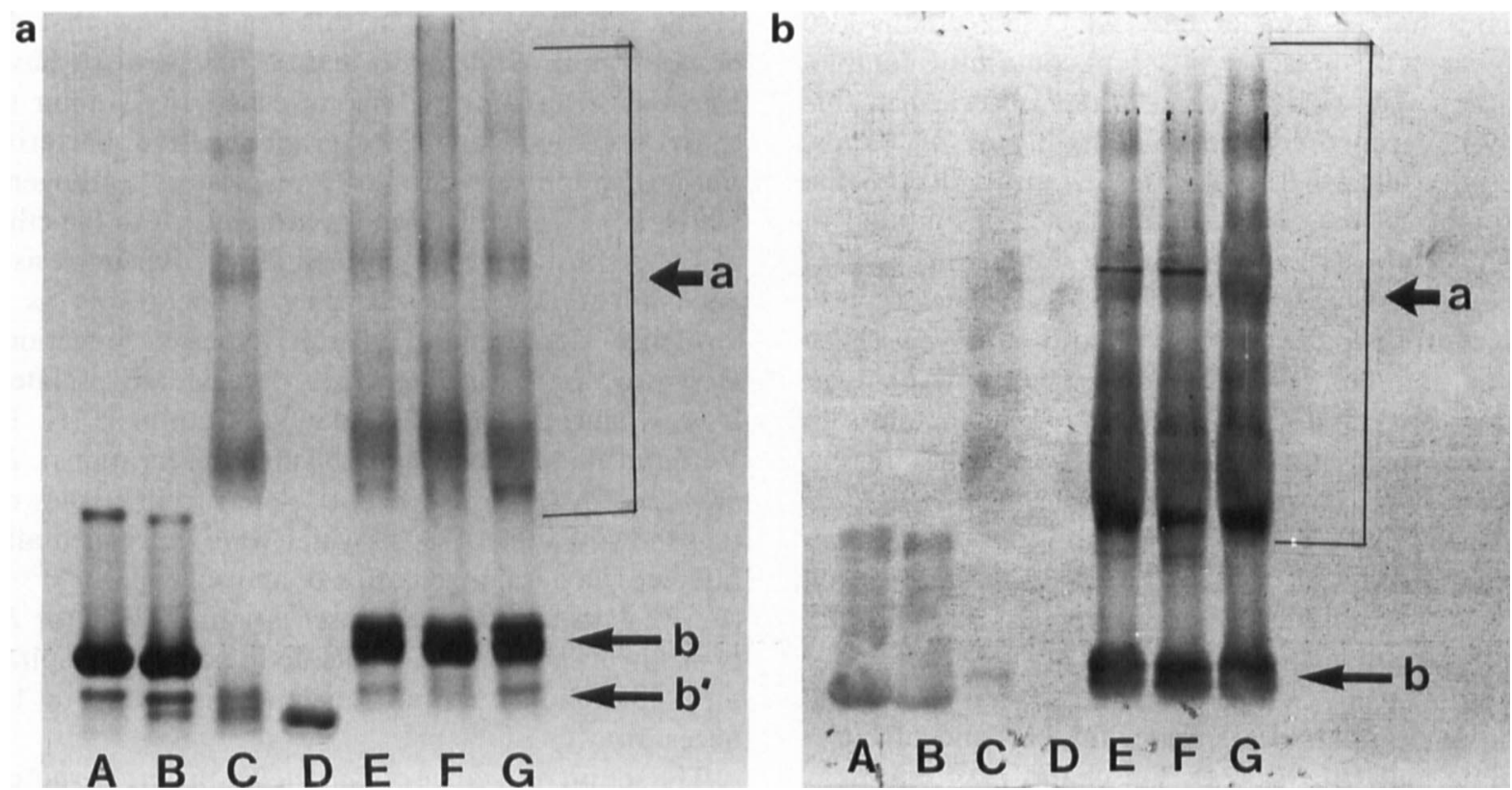

Fig. 2. (a) Silver-stained SDS-PAGE profiles of proteinase K-treated LPS preparations from Bordetella strains. (b) Western blot analysis of LPS preparations from Bordetella strains with porcine hyperimmune serum. Lane A, B. pertussis Bp-338; B, B. pertussis ATCC 9797; C, B. parapertussis ATCC 15311 ; D, B. bronchiseptica CSU-P-1; E, B. bronchiseptica B205BT; F, B. bronchiseptica 64-C-0406; G, B. bronchiseptica 1120-A-83-013. Arrow a points to zone of high mol. wt bands interpreted to contain O-side chain-like materials. Arrows b,b' point to zones of lower mol. wt bands, interpreted as core structures.

chains on core structure fragments. B. bronchiseptica strains B205BT, 64-C-0406 and 1120-A-83-013 and both $B$. pertussis strains had bands which occupied similar mol. wt ranges on silver-stained SDS-PAGE gels (fig. 2a identified as $b$ and $b^{\prime}$ ), but such bands were absent from $B$. parapertussis and $B$. bronchiseptica strain CSU-P-1. These lower mol. wt bands were thought to represent primarily core structures with small to non-existent $\mathrm{O}$-side chains.

\section{Western blot analysis}

The high mol. wt region (fig. 2a, identified as "a") of $B$. bronchiseptica strains B205BT, 64-C-0406 and 1120-A-83-013 and B. parapertussis strain ATCC 15311 developed a positive reaction on nitrocellulose paper when exposed to porcine hyperimmune serum. The lower mol. wt bands of all Bordetella strains tested, except for $B$. bronchiseptica strain CSU-P-1, gave a positive reaction when treated with porcine hyperimmune serum. Smooth B. bronchiseptica strains developed stronger reactions on nitrocellulose paper than did the $B$. parapertussis or B. pertussis strains (fig. 2b).

\section{Chromatographic analysis}

Gel filtration of oligosaccharide samples from $B$. bronchiseptica strains B205BT, 64-C-0406 and 1120-A83-013 and B. parapertussis strain ATCC 15311 on Sephadex G-75 yielded two distinct peaks of carbohydrate, with $K_{a v}$ values of 0.2 and 0.8 , where $K_{a v}$ is the distribution coefficient from the formula:

$$
K_{\mathrm{av}}=\frac{\mathrm{V}_{\mathrm{e}}-\mathrm{V}_{\mathrm{o}}}{\mathrm{V}_{\mathrm{t}}-\mathrm{V}_{\mathrm{o}}}
$$

where $V_{e}$ is the volume at which the peak elutes, $V_{o}$ the void volume of the column, and $V_{t}$ the total volume of the column. Gel filtration of oligosaccharides from $B$. bronchiseptica strain CSU-P-1 and $B$. pertussis strains ATCC 9797 and Bp-338 resolved into one distinct carbohydrate peak with a $\mathrm{K}_{\mathrm{av}}$ of 0.8 .

\section{Discussion}

The smooth strains of $B$. bronchiseptica, B205BT, 1120-A-83-013 and 64-C-0406, and the B. parapertussis strain ATCC 15311 used in this study had LPS profiles with similar high mol. wt bands which were interpreted as core structure fragments with variable length $\mathrm{O}$ side chain-like material. Similar LPS profiles on SDSPAGE for $B$. bronchiseptica and $B$. parapertussis strains have been reported by others. ${ }^{20,25}$ The smooth strains were also found to remain viable in the presence of heated or unheated pre-colostrum or hyperimmune porcine serum. Similar survival responses have been observed with strains of Escherichia coli, ${ }^{6}$ Salmonella minnesota, ${ }^{26} \mathrm{~S}$. montevideo, ${ }^{5}$ Klebsiella pneumoniae, ${ }^{8}$ Pseudomonas aeruginosa $^{7}$ and Neisseria spp. ${ }^{21}$ Protection against serum killing by complement-dependent mechanisms for these bacteria has been postulated to be a function of the size of the O-side chain. ${ }^{26}$ In some of these studies ${ }^{5,7}$ it has been found that serumresistant strains activate the complement cascade and cause the formation of the membrane attack complex (MAC). However, it is believed that the MAC can be sterically hindered from attacking the outer membrane of bacteria by the presence of high mol. wt O-side chains. This view is supported by the observation that 
variants having smaller mol. wt O-side chains lose viability in the presence of serum containing complement. ${ }^{5,21}$ The positive correlations observed in this study between the presence of high mol. wt bands, reactivity of anti- $B$. bronchiseptica antibodies to the high mol. wt bands and maintenance of viability in specific antiserum suggest that a similar mechanism for serum resistance may operate for Bordetella spp.

In contrast to the resistant smooth $B$. bronchiseptica strains and the $B$. parapertussis strain, $B$. pertussis strains Bp-338 and ATCC 9797 lost viability in unheated hyperimmune porcine serum, but not in unheated pre-colostrum porcine serum. SDS-PAGE profiles indicated that the LPS of the $B$. pertussis strains lacked high mol. wt bands, suggesting a lack of long O-side chains. Their serum resistance and LPS profiles are thus similar to those of Neisseria ${ }^{21,27,28}$ and Haemophilus ${ }^{29}$ spp. It was noted that the two $B$. pertussis strains had a similar unique band of intermediate mol. wt (fig. 2a). This band may represent core protein fragments with intermediate length $\mathrm{O}$ side chains. Others have shown that LPS profiles of $B$. pertussis strains contain intermediate to small mol. wt bands typical of O-side chain material. ${ }^{2,20,28}$ This latter type of LPS has been referred to by some as a "lipo-oligosaccharide" or LOS. ${ }^{21,28}$ Specific antibodies, i.e., those directed against certain outer-membrane proteins, allow the MAC to form at sites on the outer membrane of such bacteria where it can effectively induce cell lysis. ${ }^{26}$ Gram-negative bacteria with this type of LPS are usually susceptible to loss of viability only in the presence of specific antibodies. ${ }^{26}$ Serum sensitivity of the $B$. pertussis strains used in this study showed this relationship.

B. bronchiseptica strain CSU-P-1 lost viability in both unheated pre-colostrum and hyperimmune porcine serum, suggesting that neither specific antibody nor immunoglobulins in general are necessary for the loss. This strain has a rough colonial morphology on BGS, ${ }^{10}$ and LPS profiles on SDS-PAGE indicate that it has a low mol. wt core structure with no apparent O-side chain-like material present, similar to the LPS of deep rough mutants described for Salmonella spp. ${ }^{30}$ It has been shown that the lipid-A of some bacterial species is capable of binding complement components and activating the complement pathway in the absence of specific antibodies. ${ }^{31}$ Possibly, the lipid-A of CSUP-1 is sufficiently exposed to activate the complement pathway.

\section{References}

1. Weiss AA, Hewlett EL. Virulence factors of Bordetella pertussis. Annu Rev Microbiol 1986; 40; 661-686.

2. Linnemann CC, Perry EB. Bordetella parapertussis. Am $J$ Dis Child 1977; 131 : 560-563.

3. Goodnow RA. Biology of Bordetella bronchiseptica. Microbiol Rev 1980; 44: 722-738.

4. Byrd LH, Anama L, Gutkin M, Chmel H. Bordetella bronchiseptica peritonitis associated with continuous ambulatory peritoneal dialysis. J Clin Microbiol 1981; 14: 232-233.
The results outlined in this report show that $B$. bronchiseptica, $B$. pertussis and $B$. parapertussis have LPS characteristics and serum sensitivity similar to those observed for other gram-negative bacteria. Bordetella spp. are primarily respiratory pathogens which have a predilection for attachment to the cilia of the respiratory tract epithelium; $;^{3,32}$ serum resistance apparently does not play a major role as a virulence determinant in this type of infection. However, $B$. bronchiseptica is occasionally isolated from wound infections in $\operatorname{man}^{4}$ and animals $(H$. $P$. Veit and R. M. Roop, unpublished observations). $\boldsymbol{B}$. bronchiseptica has also been isolated from tissues of pigs showing signs of sepsis which were experimentally infected via nasal inoculation or aerosol exposure ${ }^{33,34}$ (H. P. Veit, unpublished observations). Thus, for $B$. bronchiseptica to colonise outside the ciliated respiratory epithelium, serum resistance is likely to be necessary.

The serum resistance of Bordetella spp. in vitro noted in this study correlated well with clinical observations of invasiveness in vivo for all strains examined except one, B. parapertussis strain ATCC 15311. This strain had high mol. wt $\mathrm{O}$-side chain-like material and serum resistance, but has not been reported to cause infection outside the respiratory tract. ${ }^{1}$ It is possible that this strain would have shown serum sensitivity if in vitro periods longer than $60 \mathrm{~min}$ had been used. There was an observable trend (not significant, $p<0.05$ ) for reduced viability of this strain between 20 and $60 \mathrm{~min}$. Longer exposure to serum in vitro would have more closely mimicked in-vivo conditions. Also, B. parapertussis strain ATCC 15311 had lower mol. wt core structures, compared to the core structures of the smooth $B$. bronchiseptica strains which are known to be invasive in vivo. Possibly, the core structures are important for long term (at least, greater than $60 \mathrm{~min}$ ) serum resistance, and viability in vivo.

We concluded that the Bordetella strains that developed high mol. wt bands (interpreted as long $\mathrm{O}$ side chain-like material) and higher mol. wt core structures (fig. 2a, identified as " $b$ ") are resistant to antibody and complement-mediated reduction in viability in vitro, and that such resistance closely correlates with the ability of such strains to infect outside the respiratory epithelium in vivo.

We acknowledge the fine technical assistance of Dr T. Inzana in this work.

5. Grossman N, Schmetz MA, Foulds J et al. Lipopolysaccharide size and distribution determine serum resistance in Salmonella montevideo. J Bacteriol 1987; 169: 856-863.

6. Porat R, Johns MA, McCabe WR. Selective pressures and lipopolysaccharide subunits as determinants of resistance of clinical isolates of gram-negative bacilli to human serum Infect Immun 1987; 55: 320-328.

7. Schiller NL, Joiner KA. Interaction of complement with serumsensitive and serum-resistant strains of Pseudomonas aeruginosa. Infect Immun 1986; 54: 689-694.

8. Tomás JM, Benedí VJ, Ciurana B, Jofre J. Role of capsule and 
$O$ antigen in resistance of Klebsiella pneumoniae to serum bactericidal activity. Infect Immun 1986; 54: 85-89.

9. Peppler MS, Schrumpf ME. Phenotypic variation and modulation in Bordetella bronchiseptica. Infect Immun 1984; 44: 681-687.

10. Roop RM, Veit HP, Sinsky RJ, Veit SP, Hewlett EL, Kornegay ET. Virulence factors of Bordetella bronchiseptica associated with the production of infectious atrophic rhinitis and pneumonia in experimentally infected neonatal swine. Infect Immun 1986; 55: 217-222.

11. Renshaw HW, Gilmore RJ. Alternative and classical complement pathway activity in sera from colostrum-fed and colostrum-deprived neonatal pigs. Immunology 1980; 41 : 203-209.

12. Klaassen JM, Bernard BL, Digiacomo RF. Enzyme-linked immunosorbent assay for immunoglobulin $\mathrm{G}$ antibody to Pasteurella multocida in rabbits. J Clin Microbiol 1985; 21 : 617-621.

13. Venier L, Rothschild MF, Warner CW. Measurement of serum antibody in swine vaccinated with Bordetella bronchiseptica: comparison of agglutination and enzyme-linked immunosorbent assay methods. Am J Vet Res 1984; 45: 2634-2636.

14. Lowry OH, Rosebrough NJ, Farr AL, Randall RJ. Protein measurement with the Folin phenol reagent. J Biol Chem 1952; 193: 265-275.

15. Stainer DW, Scholte MJ. A simple chemically defined medium for the production of phase I Bordetella pertussis. J Gen Microbiol 1970; 63: 211-220.

16. Westphal O, Jann $K$. Bacterial lipopolysaccharides. Extraction with phenol-water and further applications of the procedure. In: Whistler RL (ed) Methods in carbohydrate chemistry, vol 5. New York, Academic Press. 1965: 8391.

17. Cross AS, Kim KS, Wright DC, Sadoff JC, Gemski P. Role of lipopolysaccharide and capsule in the serum resistance of bacteremic strains of Escherichia coli. J Infect Dis 1986; 154: 497-503.

18. Hitchcock PJ, Brown TM. Morphological heterogeneity among Salmonella lipopolysaccharide chemotypes in silver-stained polyacrylamide gels. J Bacteriol $1983 ; 154: 269-277$.

19. Laemmli UK. Cleavage of structural proteins during the assembly of the head of bacteriophage T4. Nature 1970; 227: $680-685$.

20. Peppler MS. Two physically and serologically distinct lipopolysaccharide profiles in strains of Bordetella pertussis and their phenotype variants. Infect Immun 1984; 43: 224-232.

21. Schneider H, Hale TL, Zollinger WD, Seid RC, Hammack CA,
Griffiss JM. Heterogeneity of molecular size and antigenic expression within lipooligosaccharides of individual strains of Neisseria gonorrhoeae and Neisseria meningitidis. Infect Immun 1984; 45: 544-549.

22. Tsai C-M, Frasch CE. A sensitive silver stain for detecting lipopolysaccharides in polyacrylamide gels. Anal Biochem 1982; 119: 115-119.

23. Towbin H, Staehelin T, Gordon J. Electrophoretic transfer of proteins from polyacrylamide gels to nitrocellulose sheets: procedure and some applications. Proc Natl Acad of Sci USA $1979 ; 76: 4350-4354$.

24. Dubois M, Gilles KA, Hamilton JK, Rebers PA, Smith F. Colorimetric method for determination of sugars and related substances. Anal Chem 1956; 28: 350-356.

25. Paloheimo M, Olander RM, Runebergnyman K. Failure to convert Bordetella parapertussis to Bordetella pertussis with a pertussis phage. FEMS Microbiol Lett 1987; 41 : 79-83.

26. Frank MM, Joiner $K$, Hammer $C$. The function of antibody and complement in the lysis of bacteria. Rev Infect Dis 1987; 9 Suppl 5: S537-S545.

27. Tsai C-M, Mocca LF, Frasch CE. Characterization of the antigenic components in eight lipooligosaccharide immunotypes of Neisseria meningitidis. In: Schoolnik GK (ed) The pathogenic Neisseria. Washington, DC, American Society for Microbiology 1985: 556-561.

28. Wu LH, Tsai C-M, Frasch CE. A method for purification of bacterial R-type lipopolysaccharides (lipooligosaccharides). Anal Biochem 1987; 160: 281-289.

29. Inzana TJ, Seifert WE, Williams RP. Composition and antigenic activity of the oligosaccharide moiety of Haemophilus influenzae type b lipooligosaccharide. Infect Immun $1985 ; 48: 324-330$

30. Vukajlovich SW. Antibody-independent activation of the classical pathway of human serum complement by lipid A is restricted to Re-chemotype lipopolysaccharide and purified lipid A. Infect Immun 1986; 53: 480-485.

31. Morrison DC, Kline LF. Activation of the classical and properdin pathways of complement by bacterial lipopolysaccharides (LPS). J Immunol 1977; 118: 362-368.

32. Tuomanen EI, Nedelman J, Hendley JO, Hewlett EL. Species specificity of Bordetella adherence to human and animal ciliated respiratory epithelial cells. Infect Immun 1983; 42: 692-695.

33. Brassinne $\mathbf{M}$, Dewaele $A$, Gouffaux M. Intranasal infection with Bordetella bronchiseptica in gnotobiotic piglets. Res Vet Sci 1976; 20: 162-166.

34. Miniats OP, Johnson JA. Experimental atrophic rhinitis in gnotobiotic pigs. Can J Comp Med 1980; 44: 358-365. 
